\title{
WATER STRESS EFFECTS ON CHLOROPHYLL FLUORESCENCE AND CHLOROPHYLL CONTENT IN SUGARCANE CULTIVARS WITH CONTRASTING TOLERANCE
}

\author{
EFEITOS DO ESTRESSE HÍDRICO NA FLUORESCÊNCIA E CONTEÚDO DE \\ CLOROFILA EM CULTIVARES DE CANA-DE-AÇÚCAR COM TOLERÂNCIA \\ CONTRASTANTE
}

\author{
Marcelo de Almeida SILVA ${ }^{\mathbf{1}}$; Renata Passos PINCELLI ${ }^{\mathbf{1}}$; Alexandrius de Moraes BARBOSA ${ }^{\mathbf{2}}$ \\ 1. Universidade Estadual Paulista (UNESP), Faculdade de Ciências Agronômicas, Departamento de Produção e \\ Melhoramento Vegetal, Botucatu, SP, Brasil.; 2. Universidade do Oeste Paulista (UNOESTE), Departamento de Produção Vegetal, \\ Presidente Prudente, SP, Brasil. marcelosilva@fca.unesp.br
}

\begin{abstract}
One way to minimize the impacts caused by water deficit (WD) in agriculture is the use of tolerant cultivars. The physiological evaluation of plants through the potential quantum efficiency of photosystem II $(\mathrm{Fv} / \mathrm{Fm})$ and estimated chlorophyll content (SPAD index) can be an effective tool in the selection and recommendation of water deficit-tolerant cultivars. Within this context, the aim of this study was to evaluate the physiological responses of sugarcane cultivars classified as tolerant or susceptible to water deficit. The experiment was carried out near the city of Jaú, SP, Brazil in a greenhouse, between July and December 2013. The experimental design was completely randomized in a 4 x 2 factorial arrangement, with four replications. We studied four sugarcane cultivars: RB72454, RB855453 (prone to WD), SP81-3250 and SP83-2847 (WD-tolerant) in two water management regimes (with and without deficit). WD reduced stems dry mass of all cultivars, however, the greatest decreases were observed in susceptible cultivars to WD, where the decrease was 58.3 and $74.5 \%$ for cultivars RB855443 and RB72454, respectively. As for the SP81-3250 and SP83-2847 cultivars (tolerant), the reduction was 44.1 and 47.7\%, respectively. For water deficit-tolerant cultivars, there was lower reduction in potential quantum efficiency of photosystem II and SPAD index; therefore, the physiological characteristics (Fv/Fm and SPAD index) are features that can aid the identification and selection of water deficit tolerant cultivars, and also help the recommendation of these cultivars for harsh environments, minimizing the effects of water deficit on stem yield on the sugarcane crop.
\end{abstract}

KEYWORDS: Saccharum spp.. SPAD index. Water stress. Potential quantum efficiency of photosystem II. Photosynthetic pigments.

\section{INTRODUCTION}

Brazil is the largest producer of sugarcane, and the cultivated area was approximately 8.9 million hectares in 2015/16 (CONAB, 2015). The national average productivity of sugarcane in the 2014/15 harvest was $70.49 \mathrm{t} \mathrm{ha}^{-1}$, quite below the genetic potential of the crop, which can reach $212 \mathrm{t}$ $\mathrm{ha}^{-1}$, according to Waclawovsky et al. (2010). Water deficit is one of the several factors that limit sugarcane yield. A number of authors have reported that sugarcane yield is reduced by water stress conditions, as well as changes in the morphological characteristics of the plant, such as leaf area, number of green leaves, stem elongation and diameter (INMAM-BAMBER et al., 2005; MACHADO et al., 2009; PINCELLI; SILVA, 2012; ZHAO et al., 2013; SILVA et al., 2014a).

Reduction in photosynthetic rate is the main cause of reduced growth and yield of sugarcane plants under water deficit conditions, due to reduction of leaf expansion, stomatal closure (causing increase of temperature and reduction of internal $\mathrm{CO}_{2}$ concentration) and change in carbon allocation (GRACE et al, 2010; SATO et al., 2010; ZHAO et al., 2013; SILVA et al., 2013; BARBOSA et al., 2015). The limitation of photosynthesis under water deficit conditions can be caused by photoinhibition, which is a complex set of molecular mechanisms that promote inhibition of photosynthesis by light excess (ALMENARA, 1998). According to Baker (1993), plants subjected to water deficit often have a marked photoinhibitory effect, characterized by a significant decrease in quantum yield. In this case, water stress in combination with high levels of irradiation may cause a significant decrease in photosynthesis.

The intensity of the photoinhibition can be measured by the reduction of the potential quantum efficiency of photosystem (PS) II (Fv/Fm) (LONG et al., 1994). This index represents the energy transmitted to the PSI by the electron transport chain and is converted into chemical energy (PIMENTEL, 2014). The $\mathrm{Fv} / \mathrm{Fm}$ ratio can vary within a range of 0.75 to 0.85 for normal plants in optimum conditions (KRAUSE; WEIS, 1991). The 
decrease in this ratio is an indicator of the photoinhibitory effect when plants are subjected to stress (BJÖRKMAN; POWLES, 1984).

The photosynthetic pigments are often used to estimate the photosynthetic capacity of plants, since their contents can vary between species, as well as between genotypes of the same species (CIGANDA et al., 2008). The SPAD index is one physiological parameter that can help identify plants that are photoinhibited. According to Torres Netto et al. (2005), the indirect determination of leaf chlorophyll content can be used as a tool to diagnose the integrity of the photosynthetic apparatus, when plants are exposed to environmental adversities.

In order to make the selection of water deficit tolerant and/or susceptible cultivars, several studies have been recently conducted on analysis of $\mathrm{Fv} / \mathrm{Fm}$ and SPAD index in sugarcane under water deficit. Advantages of this analysis include speed of data collection and use of non-destructive samples (SILVA et al., 2011, 2014b).

Thus, one way to minimize the impacts caused by water deficit is the identification and selection of water deficit tolerant and susceptible cultivars through these physiological variables. However breeders are still looking for traits that are suitable for screening sugarcane germplasm for characters affecting plant water relations under drought conditions. Besides, this information may help the recommendation of tolerant cultivars for production environments that have a higher risk of water stress during the crop growing season.

Based on this context, this research aimed to evaluate how four sugarcane cultivars classified as tolerant or susceptible, deal with water deficiency according to some physiological characteristics.

\section{MATERIAL AND METHODS}

The experiment was carried out at the Research and Development Unit of the São Paulo Agency for Agribusiness Technology (APTA) in the city of Jaú/SP in the greenhouse, between July and December 2013. Air temperature was monitored through a portable hygrometer (Acurite, China), with average maximum air temperature of $24.4 \pm 3.7^{\circ} \mathrm{C}$ and average minimum temperature of $16.4 \pm 2.5{ }^{\circ} \mathrm{C}$. Irradiation was monitored by a quantometer (Apogee Model QMSS-E Quantum PAR Meter, Logan, UT, USA), with a mean of $820.0 \mu \mathrm{mol} \mathrm{m}^{-2} \mathrm{~s}^{-1}$.

The experimental design was completely randomized in a $4 \times 2$ factorial arrangement, with four replications. We evaluated four sugarcane cultivars (RB72454, RB855453, SP81-3250 and SP83-2847) in two water regimes (with and without deficit). The experimental plot consisted of $22.0 \mathrm{~L}$ plastic pots. The cultivars SP81-3250 and SP832847 were used as tolerant to the water deficit (GONÇALVES, 2008) and cultivars RB72454 and RB855453 were used as susceptible (DEDEMO, 2006).

Three mini-stalks of sugarcane were planted in each pot, filled with sterile substrate comprised of expanded vermiculite and organic material mixed with $55.0 \mathrm{~g}$ of formulated fertilizer NPK 08-28-16. After sprouting, only one plant was maintained per pot; during development, tillers were cut, and only the primary tiller was left.

Substrate humidity was monitored three times a day (7 am, $12 \mathrm{pm}$ and $4 \mathrm{pm}$ ) through an $\mathrm{ECH}_{2} \mathrm{O}$ meter (Decagon, Pullman, WA, USA). Up to 84 days after planting (DAP), plants were irrigated properly, and substrate humidity remained around $22 \%$ (corresponding to $100 \%$ of field capacity). Treatment with water deficit began after 84 DAP, and in this treatment the moisture substrate was maintained at $11 \%$ (50\% of field capacity); for the control treatment, moisture remained at $22 \%$ by the end of the experiment ( 140 DAP), according to the methodology used by Silva et al. (2013).

Evaluations of chlorophyll and chlorophyll fluorescence occurred at 0,28 and 56 days after onset the treatments (DAT) on the middle third between the central rib and the edge of the leaf +1 (first fully expanded leaf with apparent ligule). To evaluate the estimated chlorophyll content (SPAD index), a SPAD-502 chlorophyll meter (Minolta Corp., Ramsey, NJ, USA) was used. The average of the plot (pot) was considered for three readings in the +1 leaves. The SPAD index corresponds to leaf pigment content, and its value is equivalent to the amount of light transmitted through the leaf at two wavelength regions where chlorophyll absorption is different (MALAVOLTA et al., 1997).

Potential quantum efficiency of photosystem II $(\mathrm{Fv} / \mathrm{Fm})$ was determined in the leaves +1 with a portable fluorometer (model OS30p, Opti-Sciences, Inc., Hudson, NH, USA). In order to obtain $\mathrm{Fv} / \mathrm{Fm}$ readings, special clips were used to pre-dark the leaves for about 30 minutes. The variable $\mathrm{Fv} / \mathrm{Fm}$ was determined following the procedures of Maxwell and Johnson (2000), where Fm is the maximum fluorescence intensity in all the reactions of photosystem II (PSII) are closed; F0 is the minimum fluorescence intensity when the PSII reaction centers are open, and $\mathrm{Fv}$ is the variable 
fluorescence $(\mathrm{Fv}=\mathrm{Fm}-\mathrm{F} 0)$. The reading was held at $10 \mathrm{am}$.

Chlorophyll content $\left(\mathrm{Chl}, \mu \mathrm{g} \mathrm{cm}^{-2}\right)$ was estimated using a spectrophotometer (model DU 720, Beckman, Fullerton, CA, USA), and two leaf discs $\left(0.69 \mathrm{~cm}^{2}\right.$ each one) extracted with a puncher, between the edge and the central rib from the middle third of the leaf +1 . Chl was determined according to the methodology of Damn et al. (1989); the method is based on the use of $1 \mathrm{~mL}$ of chlorophyll extract obtained by extraction from the solvent dimethyl formamide (DMF). The solution was kept sheltered from light for $24 \mathrm{~h}$ to complete the extraction. Immediately after that, absorbance reading was performed using a spectrophotometer at wavelengths of 647 and $664 \mathrm{~nm}$; the reading was performed on $1 \mathrm{~mL}$ of chlorophyll extract diluted in $1 \mathrm{~mL}$ of deionized water. Results for chlorophyll content were obtained in the following combinations: $\mathrm{Chl} a, \mathrm{Chl} b, \mathrm{Chl} a+b$ (total) and Chl $a / b$.

For leaf relative water content (RWC), we determined fresh mass (Mf), turgid mass (Mt) and dry mass $(\mathrm{Md})$ in leaf discs $\left(0,69 \mathrm{~cm}^{2}\right.$ each) extracted from the middle third of the leaves +2 . Leaf disk fresh weights were determined within $2 \mathrm{~h}$ after excision. The turgid weight was obtained after rehydration in deionized water for $24 \mathrm{~h}$ at room temperature. After rehydration, leaves were quickly and carefully blotted dry with lint-free tissue paper before determining turgid weight. Dry weights were recorded after oven-drying leaf samples for $48 \mathrm{~h}$ at $80^{\circ} \mathrm{C}$. RWC was calculated following the method of
Matin et al. (1989) with the equation: RWC $=[(\mathrm{Mf}$ $\left.-\mathrm{Md}) \times(\mathrm{Mt}-\mathrm{Md})^{-1}\right] \times 100$.

Whole plants were harvested at 140 DAP to obtain separate samples of stems, leaves and roots. Leaf dry weight, root dry weight and stem dry mass were measured after dried at $65{ }^{\circ} \mathrm{C}$ to constant weight.

For data analysis, we used the statistical treatment of individual characteristics. Analysis of variance was performed followed by multiple comparison test applying the Tukey's HSD with a significance of $p<0.05$ to compare the means. When the interaction between the factors was significant, the analysis was performed after the unfolding.

\section{RESULTS}

There were no differences among cultivars for biometric variables (leaf dry weight, root dry weight and stem dry mass) (Table 1). It was observed that water deficit reduced leaf dry matter, root dry matter and stem dry matter in all cultivars. However, it should be noted that the greatest reductions in dry matter of leaf and stem occurred in cultivars considered as prone to water deficit. The reductions for these cultivars were 46.1 and $40.4 \%$ and 58.3 and $74.5 \%$ for leaf and stem, respectively (RB855453 and RB72454, respectively), while for water deficit-tolerant cultivars (SP81-3250 and SP83-2847), reductions were 31.2 and $23.0 \%$ (leaf) and 44.1 and $47.7 \%$ (stem) (Table 2).

Table 1. Analysis of variance for biometric variables, dry matter of leaves (g) (Leaf DM), roots (g) (Root DM), stem $(\mathrm{g})($ Stem $D M)$, of four sugarcane cultivars under two water regimes.

\begin{tabular}{llll}
\hline Treatment & Leaf DM & Root DM & Stem DM \\
\hline Cultivar & & & \\
RB855453 (S) & 246.75 & 55.00 & 455.62 \\
RB72454 (S) & 223.25 & 68.75 & 412.62 \\
SP81-3250 (T) & 221.75 & 67.87 & 499.00 \\
SP83-2487 (T) & 249.25 & 75.87 & 623.50 \\
\hline Water regime & & & \\
Control & $287.45 \mathrm{a}$ & $87.81 \mathrm{a}$ & $696.12 \mathrm{a}$ \\
Deficit & $182.75 \mathrm{~b}$ & $45.93 \mathrm{~b}$ & $229.25 \mathrm{~b}$ \\
\hline F & & & \\
Cultivar (C) & $1.29 \mathrm{~ns}$ & $1.67 \mathrm{~ns}$ & $2.64 \mathrm{~ns}$ \\
Water regime (W) & $65.31^{* *}$ & $38.92^{* *}$ & $50.24^{* *}$ \\
C x W & $1.59 \mathrm{~ns}$ & $2.15 \mathrm{~ns}$ & $0.54 \mathrm{~ns}$ \\
\hline CV $(\%)$ & 15.62 & 28.39 & 31.82 \\
\hline
\end{tabular}

Averages followed by different letters indicate differences in each characteristic (Tukey's test: $\mathrm{p}<0.05$ ). $\mathrm{S}$ and $\mathrm{T}$ mean water deficit susceptible and tolerant cultivars, respectively. $\mathrm{ns}=$ Not significant. $* *$ Significant at the 0.01 probability level. 
Table 2. Average values of dry matter leaves $(\mathrm{g})$, roots $(\mathrm{g})$ and stem $(\mathrm{g})$ of four sugarcane cultivars under two water regimes, and difference $(\Delta, \%)$ of dry matter between without and with water deficit treatments.

\begin{tabular}{|c|c|c|c|}
\hline \multirow{3}{*}{ Cultivar } & \multicolumn{2}{|c|}{ Dry matter of leaf (g) } & \multirow{3}{*}{$\Delta(\%)$} \\
\hline & \multicolumn{2}{|c|}{ Water regime } & \\
\hline & $100 \%$ & $50 \%$ & \\
\hline RB855453 (S) & 320.0 & 172.6 & 46.1 \\
\hline RB72454 (S) & 279.7 & 166.6 & 40.4 \\
\hline SP81-3250 (T) & 262.6 & 180.7 & 31.2 \\
\hline SP83-2847 (T) & 287.7 & 210.7 & 23.0 \\
\hline \multicolumn{4}{|c|}{ Dry matter of root $(\mathrm{g})$} \\
\hline RB855453 (S) & 80.7 & 46.0 & 43.0 \\
\hline RB72454 (S) & 98.2 & 37.4 & 61.9 \\
\hline SP81-3250 (T) & 83.8 & 48.9 & 41.6 \\
\hline SP83-2847 (T) & 95.9 & 41.6 & 56.6 \\
\hline \multicolumn{4}{|c|}{ Dry matter of stem $(\mathrm{g})$} \\
\hline RB855453 (S) & 631.4 & 263.0 & 58.3 \\
\hline $\mathrm{RB} 72454(\mathrm{~S})$ & 652.2 & 166.6 & 74.5 \\
\hline SP81-3250 (T) & 651.0 & 364.1 & 44.1 \\
\hline SP83-2847 (T) & 791.5 & 413.7 & 47.7 \\
\hline
\end{tabular}

$\mathrm{S}$ and $\mathrm{T}$ mean water deficit susceptible and tolerant cultivars, respectively.

The analysis of variance showed effect of cultivars in five (Fv/Fm, SPAD index, chlorophyll $a$, chlorophyll total and chlorophyll $a / b$ ratio) out of seven physiological variables; moreover, the effect of water deficit was observed in all physiological variables evaluated (Table 3 and 4).

Table 3. Analysis of variance for the potential quantum efficiency of photosystem II (Fv/Fm), SPAD index and relative water content of four sugarcane cultivars under two water regimes.

\begin{tabular}{|c|c|c|c|}
\hline \multirow{2}{*}{ Treatment } & \multicolumn{3}{|c|}{ Days after implementation of treatments } \\
\hline & 0 & 28 & 56 \\
\hline \multicolumn{4}{|c|}{ Potential quantum efficiency of photosystem II $(F v / F m)$} \\
\hline \multicolumn{4}{|l|}{ Cultivar } \\
\hline RB855453 (S) & 0.78 & $0.71 \mathrm{~B}$ & 0.75 \\
\hline RB72454 (S) & 0.79 & $0.67 \mathrm{C}$ & 0.74 \\
\hline SP81-3250 (T) & 0.79 & $0.75 \mathrm{~A}$ & 0.75 \\
\hline SP83-2487 (T) & 0.77 & $0.77 \mathrm{~A}$ & 0.75 \\
\hline \multicolumn{4}{|l|}{ Water regime } \\
\hline Control & 0.79 & $0.78 \mathrm{a}$ & $0.77 \mathrm{a}$ \\
\hline Deficit & 0.77 & $0.66 \mathrm{~b}$ & $0.73 \mathrm{~b}$ \\
\hline \multicolumn{4}{|l|}{$\mathrm{F}$} \\
\hline Cultivar (C) & $5.0 \mathrm{~ns}$ & $32.9 * *$ & $0.5 \mathrm{~ns}$ \\
\hline Water regime $(\mathrm{W})$ & $24.7 \mathrm{~ns}$ & $225.6 * *$ & $15.7 * *$ \\
\hline $\mathrm{C} \times \mathrm{W}$ & $0.8 \mathrm{~ns}$ & $22.7 * *$ & $2.6 \mathrm{~ns}$ \\
\hline \multirow[t]{2}{*}{$\mathrm{CV}(\%)$} & 1.44 & 3.04 & 3.19 \\
\hline & \multicolumn{3}{|c|}{ SPAD index } \\
\hline \multicolumn{4}{|l|}{ Cultivar } \\
\hline RB855453 (S) & 56.62 & $32.63 \mathrm{C}$ & $34.36 \mathrm{~B}$ \\
\hline RB72454 (S) & 51.66 & $40.60 \mathrm{~B}$ & $36.71 \mathrm{~B}$ \\
\hline SP81-3250 (T) & 49.35 & $45.33 \mathrm{~A}$ & $48.00 \mathrm{~A}$ \\
\hline SP83-2487 (T) & 54.51 & $47.85 \mathrm{~A}$ & $49.40 \mathrm{~A}$ \\
\hline \multicolumn{4}{|l|}{ Water regime } \\
\hline Control & 52.82 & $51.10 \mathrm{a}$ & $47.85 \mathrm{a}$ \\
\hline Deficit & 53.25 & $32.10 \mathrm{~b}$ & $36.39 \mathrm{~b}$ \\
\hline \multirow{2}{*}{\multicolumn{4}{|c|}{$\begin{array}{l}\text { F } \\
\text { Cultivar (C) }\end{array}$}} \\
\hline & $6.3 \mathrm{~ns}$ & $78.4 * *$ & $27.3 * *$ \\
\hline
\end{tabular}




\begin{tabular}{|c|c|c|c|}
\hline Water regime $(\mathrm{W})$ & $0.1 \mathrm{~ns}$ & $631.9 * *$ & $60.9 * *$ \\
\hline $\mathrm{C} \times \mathrm{W}$ & $2.6 \mathrm{~ns}$ & $56.9 * *$ & $11.0 * *$ \\
\hline \multirow[t]{2}{*}{$\mathrm{CV}(\%)$} & 6.78 & 5.14 & 9.85 \\
\hline & \multicolumn{3}{|c|}{ Relative water content (RWC) } \\
\hline \multicolumn{4}{|l|}{ Cultivar } \\
\hline RB855453 (S) & 92.45 & 86.03 & 87.29 \\
\hline RB72454 (S) & 91.07 & 85.36 & 85.57 \\
\hline SP81-3250 (T) & 90.40 & 89.85 & 88.49 \\
\hline SP83-2487 (T) & 90.54 & 88.64 & 86.29 \\
\hline \multicolumn{4}{|l|}{ Water regime } \\
\hline Control & 92.07 & $93.79 \mathrm{a}$ & $92.06 \mathrm{a}$ \\
\hline Deficit & 90.16 & $81.15 \mathrm{~b}$ & $81.76 \mathrm{~b}$ \\
\hline \multicolumn{4}{|l|}{$\mathrm{F}$} \\
\hline Cultivar (C) & $0.5 \mathrm{~ns}$ & $1.4 \mathrm{~ns}$ & $1.0 \mathrm{~ns}$ \\
\hline Water regime $(\mathrm{W})$ & $2.2 \mathrm{~ns}$ & $49.6 * *$ & $71.2 * *$ \\
\hline $\mathrm{C} \times \mathrm{W}$ & $0.2 \mathrm{~ns}$ & $0.2 \mathrm{~ns}$ & $0.4 \mathrm{~ns}$ \\
\hline CV (\%) & 3.95 & 5.80 & 3.97 \\
\hline
\end{tabular}

Table 4. Analysis of variance for chlorophyll $a$ and $b$ content (Chl $a$ and $b$ ), total chlorophyll content (total $\mathrm{Chl})$ and chlorophyll $a / b$ ratio (Chl $a / b$ ) of four sugarcane cultivars under two water regimes.

\begin{tabular}{|c|c|c|c|}
\hline \multirow{2}{*}{ Treatment } & \multicolumn{3}{|c|}{ Days after implementation of treatments } \\
\hline & 0 & 28 & 56 \\
\hline & \multicolumn{3}{|c|}{ Chlorophyll $a(C h l a)$} \\
\hline \multicolumn{4}{|l|}{ Cultivar } \\
\hline RB855453 (S) & 54.89 & 41.26 & $33.39 \mathrm{~B}$ \\
\hline RB72454 (S) & 50.56 & 42.85 & $45.18 \mathrm{AB}$ \\
\hline SP81-3250 (T) & 55.15 & 48.06 & $52.74 \mathrm{~A}$ \\
\hline SP83-2487 (T) & 48.38 & 43.58 & $43.24 \mathrm{AB}$ \\
\hline \multicolumn{4}{|l|}{ Water regime } \\
\hline Control & 48.96 & $49.95 \mathrm{a}$ & $52.34 \mathrm{a}$ \\
\hline Deficit & 55.53 & $37.92 \mathrm{~b}$ & $34.93 \mathrm{~b}$ \\
\hline \multicolumn{4}{|l|}{$\mathrm{F}$} \\
\hline Cultivar (C) & $4.60 \mathrm{~ns}$ & $1.95 \mathrm{~ns}$ & $6.10 * *$ \\
\hline Water regime (W) & $17.92 \mathrm{~ns}$ & $33.33 * *$ & $29.17 * *$ \\
\hline $\mathrm{C} \times \mathrm{W}$ & $2.14 \mathrm{~ns}$ & $4.05 *$ & $0.91 \mathrm{~ns}$ \\
\hline \multirow[t]{2}{*}{$\mathrm{CV}(\%)$} & 8.39 & 13.42 & 20.88 \\
\hline & \multicolumn{3}{|c|}{ Chlorophyll $b(C h l b)$} \\
\hline \multicolumn{4}{|l|}{ Cultivar } \\
\hline RB855453 (S) & 18.44 & 14.62 & 15.25 \\
\hline RB72454 (S) & 16.27 & 14.18 & 15.59 \\
\hline SP81-3250 (T) & 19.52 & 15.76 & 17.68 \\
\hline SP83-2487 (T) & 16.67 & 15.54 & 16.40 \\
\hline \multicolumn{4}{|l|}{ Water regime } \\
\hline Control & 17.36 & $16.60 \mathrm{a}$ & $17.95 \mathrm{a}$ \\
\hline Deficit & 18.09 & $13.45 \mathrm{~b}$ & $14.51 \mathrm{~b}$ \\
\hline \multicolumn{4}{|l|}{$\mathrm{F}$} \\
\hline Cultivar (C) & $5.13 \mathrm{~ns}$ & $0.89 \mathrm{~ns}$ & $2.27 \mathrm{~ns}$ \\
\hline Water regime $(\mathrm{W})$ & $1.18 \mathrm{~ns}$ & $16.63 * *$ & $23.07 * *$ \\
\hline $\mathrm{C} \times \mathrm{W}$ & $2.06 \mathrm{~ns}$ & $2.18 \mathrm{~ns}$ & $2.66 \mathrm{~ns}$ \\
\hline \multirow[t]{2}{*}{$\mathrm{CV}(\%)$} & 10.71 & 14.95 & 12.49 \\
\hline & \multicolumn{3}{|c|}{ Total chlorophyll content (Chl total) } \\
\hline
\end{tabular}




\begin{tabular}{|c|c|c|c|}
\hline \multicolumn{4}{|l|}{ Cultivar } \\
\hline RB855453 (S) & 73.34 & 55.88 & $48.65 \mathrm{~B}$ \\
\hline $\mathrm{RB} 72454(\mathrm{~S})$ & 66.84 & 57.03 & $60.77 \mathrm{AB}$ \\
\hline SP81-3250 (T) & 74.67 & 63.83 & $70.42 \mathrm{~A}$ \\
\hline SP83-2487 (T) & 65.06 & 59.12 & $69.64 \mathrm{AB}$ \\
\hline \multicolumn{4}{|l|}{ Water regime } \\
\hline Control & 66.33 & $66.55 \mathrm{a}$ & $70.29 \mathrm{a}$ \\
\hline Deficit & 73.62 & $51.38 \mathrm{~b}$ & $49.45 \mathrm{~b}$ \\
\hline \multicolumn{4}{|l|}{$\mathrm{F}$} \\
\hline Cultivar (C) & $5.31 \mathrm{~ns}$ & $1.51 \mathrm{~ns}$ & $6.69 * *$ \\
\hline Water regime $(\mathrm{W})$ & $12.57 \mathrm{~ns}$ & $28.19 * *$ & $36.62 * *$ \\
\hline $\mathrm{C} \times \mathrm{W}$ & $2.28 \mathrm{~ns}$ & $3.52 *$ & $1.01 \mathrm{~ns}$ \\
\hline \multirow[t]{2}{*}{ CV $(\%)$} & 8.31 & 13.70 & 16.27 \\
\hline & \multicolumn{3}{|c|}{ Chlorophyll $a / b$ ratio $($ Chl $a / b)$} \\
\hline \multicolumn{4}{|l|}{ Cultivar } \\
\hline RB855453 (S) & 2.98 & $2.83 \mathrm{~B}$ & 2.20 \\
\hline $\mathrm{RB} 72454(\mathrm{~S})$ & 3.13 & $3.00 \mathrm{~A}$ & 2.87 \\
\hline SP81-3250 (T) & 2.84 & $3.04 \mathrm{~A}$ & 3.02 \\
\hline SP83-2487 (T) & 2.89 & $2.79 \mathrm{~B}$ & 2.62 \\
\hline \multicolumn{4}{|l|}{ Water regime } \\
\hline Control & 2.84 & $3.01 \mathrm{a}$ & $2.90 \mathrm{a}$ \\
\hline Deficit & 3.08 & $2.82 \mathrm{~b}$ & $2.45 \mathrm{~b}$ \\
\hline \multicolumn{4}{|l|}{$\mathrm{F}$} \\
\hline Cultivar (C) & $2.41 \mathrm{~ns}$ & $8.57 * *$ & $2.82 \mathrm{~ns}$ \\
\hline Water regime $(\mathrm{W})$ & $9.06 \mathrm{~ns}$ & $20.68 * *$ & $4.37 *$ \\
\hline $\mathrm{C} \times \mathrm{W}$ & $1.02 \mathrm{~ns}$ & $1.19 \mathrm{~ns}$ & $1.66 \mathrm{~ns}$ \\
\hline $\mathrm{CV}(\%)$ & 7.69 & 4.03 & 22.58 \\
\hline
\end{tabular}

Averages followed by different letters indicate differences in each characteristic (Tukey's test: $\mathrm{p}<0.05$ ). $\mathrm{S}$ and T mean water deficit susceptible and tolerant cultivars, respectively. $\mathrm{ns}=$ Not significant. *Significant at the 0.05 probability level. $* *$ Significant at the 0.01 probability level.

For the potential quantum efficiency of photosystem II $(\mathrm{Fv} / \mathrm{Fm})$, there was a significant interaction between cultivar and water regime at 28 DAT (Table 3). At 56 DAT there was effect of water regime, i.e., water deficit decreased $\mathrm{Fv} / \mathrm{Fm}$ (Table 3). The analysis of the effects of water stress showed a decrease in $\mathrm{Fv} / \mathrm{Fm}$ at 28 DAT in all cultivars, but the largest reductions occurred in susceptible cultivars, with the largest decrease observed in RB72454, followed by cultivar RB855453 (Table 5).

The SPAD index was affected by cultivar, water regime and the interaction between these factors at both 28 and 56 DAT (Table 3). At 28 DAT, the SPAD index was decreased in all cultivars, but showed greater reduction in susceptible cultivars (Table 6). The largest decrease occurred in RB855453, followed by cultivar RB72454. At 56 DAT, only the susceptible cultivars had its SPAD index values reduced by water deficit, while the tolerant cultivars maintained
SPAD index values similar to well-watered treatment.

Suspension of irrigation reduced the relative water content (RWC) of plants, both at 28 and at 56 DAT (Table 3). However, there was no difference between cultivars throughout the experimental period.

Regarding chlorophyll $a$ content (Chl $a$ ), it was observed significant effect for water regime and the interaction between cultivar and water regime at 28 DAT (Table 4). The unfolding of the interaction showed that $\mathrm{Chl} a$ was reduced in the cultivars RB72454, SP81-3250 and SP83-2847 under drought, although RB855453 showed low chlorophyll $a$ content even under well-watered treatment (Table 7). At 56 DAT, Chl $a$ was affected by cultivar and water regime, in which SP81-3250 had the highest chlorophyll $a$ content and RB855453 the lowest one, and the lowest Chl $a$ values were observed under water deficit (Table 4). 
Table 5. Unfolding of significant interaction between cultivar and water regime for potential quantum efficiency of photosystem II ( Fv/Fm) of four sugarcane cultivars at 28 days after the onset of water regime treatments.

\begin{tabular}{lll}
\hline \multirow{2}{*}{ Cultivar } & \multicolumn{2}{c}{ Water regime } \\
\cline { 2 - 3 } & $100 \%$ & $50 \%$ \\
\hline RB855453(S) & $0.78 \mathrm{Aa}$ & $0.65 \mathrm{ABb}$ \\
RB72454 (S) & $0.77 \mathrm{Aa}$ & $0.56 \mathrm{Bb}$ \\
SP81-3250 (T) & $0.79 \mathrm{Aa}$ & $0.71 \mathrm{ABb}$ \\
SP83-2847 (T) & $0.79 \mathrm{Aa}$ & $0.75 \mathrm{Ab}$ \\
\hline
\end{tabular}

Different uppercase letters indicate differences among cultivars and different lower case letters indicate differences between water regime treatments (Tukey's test: $\mathrm{p}<0.05$ ). S and T mean water deficit susceptible and tolerant cultivars, respectively. Four replications per treatment.

Table 6. Unfolding of significant interaction between cultivar and water regime for SPAD index of four sugarcane cultivars at 28 and 56 days after the onset of water regime treatments.

\begin{tabular}{llc}
\hline \multirow{2}{*}{ Cultivar } & \multicolumn{2}{c}{ Water regime } \\
\cline { 2 - 3 } & \multicolumn{2}{c}{28 days after implantation of treatments } \\
\cline { 2 - 3 } & $100 \%$ & $50 \%$ \\
\hline RB855453 (S) & $49.50 \mathrm{Aa}$ & $15.76 \mathrm{Cb}$ \\
RB72454 (S) & $51.70 \mathrm{Aa}$ & $29.50 \mathrm{Bb}$ \\
SP81-3250 (T) & $59.96 \mathrm{Aa}$ & $40.70 \mathrm{Ab}$ \\
SP83-2847 (T) & $53.23 \mathrm{Aa}$ & $42.46 \mathrm{Ab}$ \\
\hline & $56 \mathrm{days}$ after implantation of treatments \\
\cline { 2 - 3 } RB855453 (S) & $44.16 \mathrm{Aa}$ & $24.56 \mathrm{Bb}$ \\
RB72454 (S) & $46.83 \mathrm{Aa}$ & $26.60 \mathrm{Bb}$ \\
SP81-3250 (T) & $49.46 \mathrm{Aa}$ & $46.53 \mathrm{Aa}$ \\
SP83-2847 (T) & $50.93 \mathrm{Aa}$ & $47.86 \mathrm{Aa}$ \\
\hline
\end{tabular}

Different uppercase letters indicate differences among cultivars and different lower case letters indicate differences between water regime treatments (Tukey's test: $\mathrm{p}<0.05$ ). $\mathrm{S}$ and $\mathrm{T}$ mean water deficit susceptible and tolerant cultivars, respectively. Four replications per treatment.

Table 7. Unfolding of significant interaction between cultivar and water regime for chlorophyll $a$ content (Chl $a, \mu \mathrm{g} \mathrm{cm}^{-2}$ ) of four sugarcane cultivars at 28 days after the onset of water regime treatments.

\begin{tabular}{lll}
\hline \multirow{2}{*}{ Cultivar } & \multicolumn{2}{c}{ Water regime } \\
\cline { 2 - 3 } & $100 \%$ & $50 \%$ \\
\hline RB855453 (S) & $42.41 \mathrm{Aa}$ & $40.11 \mathrm{Aa}$ \\
RB72454 (S) & $54.18 \mathrm{Aa}$ & $31.51 \mathrm{Ab}$ \\
SP81-3250 (T) & $54.51 \mathrm{Aa}$ & $41.62 \mathrm{Ab}$ \\
SP83-2847 (T) & $48.72 \mathrm{Aa}$ & $38.44 \mathrm{Ab}$ \\
\hline
\end{tabular}

Different uppercase letters indicate differences among cultivars and different lower case letters indicate differences between water regime treatments (Tukey's test: $\mathrm{p}<0.05$ ). $\mathrm{S}$ and $\mathrm{T}$ mean water deficit susceptible and tolerant cultivars, respectively. Four replications per treatment.

Chlorophyll $b$ content $(\mathrm{Chl} b)$ was reduced by water deficit at 28 and 56 DAT regardless of the cultivar (Table 4). There were differences for total chlorophyll levels (Chl total) between water regime, and the interaction between cultivar and water regime was significant at 28 DAT. The unfolding of the interaction revealed that the $\mathrm{Chl}$ total was reduced in the cultivars RB72454, SP813250 and SP83-2847, with no difference among cultivars (Table 8). At 56 DAT there was difference for cultivars and water regime, that is, as observed for Chl $a$, SP81-3250 had the highest total chlorophyll content and RB855453 the lowest one, and the lowest $\mathrm{Chl}$ total values were observed under water deficit (Table 4). It was observed that the Chl $a / b$ ratio was reduced by drought at 28 and 56 DAT. Regarding the cultivars, there was difference in Chl $a / b$ only at 28 DAT, which cultivars RB72454 and SP81-3250 had the highest values 
Table 8. Unfolding of significant interaction between cultivar and water regime for chlorophyll total content $\left(\mathrm{Chl} a+b, \mu \mathrm{g} \mathrm{cm}^{-2}\right)$ of four sugarcane cultivars at 28 days after the onset of water regime treatments.

\begin{tabular}{lll}
\hline \multirow{2}{*}{ Cultivar } & \multicolumn{2}{c}{ Water regime } \\
\cline { 2 - 3 } & $100 \%$ & $50 \%$ \\
\hline RB855453(S) & $57.33 \mathrm{Aa}$ & $54.44 \mathrm{Aa}$ \\
RB72454 (S) & $71.50 \mathrm{Aa}$ & $42.55 \mathrm{Ab}$ \\
SP81-3250 (T) & $71.74 \mathrm{Aa}$ & $55.93 \mathrm{Ab}$ \\
SP83-2847 (T) & $65.64 \mathrm{Aa}$ & $52.60 \mathrm{Ab}$ \\
\hline
\end{tabular}

Different uppercase letters indicate differences among cultivars and different lower case letters indicate differences between water regime treatments (Tukey's test: $\mathrm{p}<0.05$ ). $\mathrm{S}$ and $\mathrm{T}$ mean water deficit susceptible and tolerant cultivars, respectively. Four replications per treatment.

\section{DISCUSSION}

In the present study, water deficit reduced stem dry matter of all studied cultivars (Tables 1 and 2). The effects of water stress on stem development are well known and have been reported by several authors. Inman-Bamber and Smith (2005) observed that drought affected the development of plant stems, and also reported that there are genotypic variations when these plants are exposed to water deficit. Dantas Neto et al. (2006) and Gava et al. (2011) observed that biomass production and stem yield were reduced when sugarcane plants are under low water availability.

As observed for dry matter of the stem, leaf dry matter of tolerant cultivars had a smaller reduction in treatment with water deficit. The reductions were 46.1 and $40.4 \%$ in the cultivars RB855453 and RB72454, and 31.2 and $23.0 \%$ in cultivars SP81-3250 and SP83-2847, respectively. The reduction of root dry matter was proportionally similar among all cultivars. Leaf area reduction has been reported in plants with water deficit and attributed to a strategy to reduce water loss through transpiration (INMAN-BAMBER; SMITH, 2005; SMIT; SINGELS; 2006). However, there is a greater reduction of the dry mass of the stem than the dry mass of the leaf, this is because the development of the stem is more affected by the water deficit than the leaf development, that is, under certain stress conditions the plant interrupts the development stem while leaf development continues (BATCHELOR et al., 1992; INMANBAMBER, 2004; INMAN-BAMBER; SMITH, 2005).

The greatest decreases in dry matter production of stems are given in cultivars considered as susceptible to water deficit. These results are consistent with the classification of these cultivars under water deficit conditions. Several studies corroborate the results observed in the present study. Silva et al. (2011) evaluated eight sugarcane genotypes (four water deficit tolerant genotypes and four water deficit susceptible ones); the authors observed that the highest yield of stems was obtained in cultivars considered as tolerant. Ribeiro et al. (2013) studied the response of three sugarcane genotypes under water deficit (two tolerant and one susceptible), and observed that most stem dry matter was produced by tolerant cultivars.

The use of water deficit tolerant cultivars is an important strategy that can promote increases in stem yield and/or assist in the recommendation of sugarcane cultivars for more stressful environments, therefore minimizing the effects of water deficit on stem yield. Usually, the main measure for classification of cultivars as tolerant or susceptible to water deficit is stem yield (Silva et al., 2008). Inman-Bamber and Smith (2005) suggested that the assessment of physiological characteristics of sugarcane genotypes submitted to water deficit can lead to a better understanding of how this acclimatization occurs, and consequently lead to an increase in stem yield and the quality of current genotypes of sugarcane.

In the present study, it was observed that at 28 days after the beginning of water deficit, a difference was observed in the potential quantum efficiency of photosystem II (Fv/Fm) among cultivars subjected to water deficit. There was a decrease of $\mathrm{Fv} / \mathrm{Fm}$ in RB72454 and RB855453 cultivars, both classified as susceptible. Fv/Fm is a physiological characteristic that has been highly used in cultivar classification as water availability.

Graça et al. (2010) evaluated the effects of drought on sugarcane cultivars for fourteen days; they observed that water deficit tolerant cultivars have higher $\mathrm{Fv} / \mathrm{Fm}$ values. Ribeiro et al. (2013) studied water deficit effects on three varieties of sugarcane at twenty-five days after the onset of drought, and these authors observed that $\mathrm{Fv} / \mathrm{Fm}$ decreased only in the cultivar considered as sensitive to water deficit. In a study of 78 sugarcane genotypes under water deficit, Silva et al. (2014a) observed a linear relationship of $66.4 \%$ between 
yield and $\mathrm{Fv} / \mathrm{Fm}$. These authors also suggested that $\mathrm{Fv} / \mathrm{Fm}$ can be a physiological characteristic used for selection of water deficit tolerant genotypes. Sugarcane varieties with ability to keep the Fv/Fm above 0.76 in water deficit conditions can be considered tolerant (SILVA et al., 2014a).

Therefore, it can be observed that $\mathrm{Fv} / \mathrm{Fm}$ is strongly correlated with the physiological characteristic of genotype tolerance to water deficit. This is due to the fact that water is the major donor of electrons to photosystem II by means of the oxidation process; thus, a reduction in water content may decrease the electrochemical potential of ATP synthase and photosystem I, compromising the formation of ATP and NADPH, respectively, and negatively affecting the photosynthetic apparatus (PIMENTEL, 2014).

At 56 DAT, there were no differences among cultivars, and $\mathrm{Fv} / \mathrm{Fm}$ was altered by water deficit in only two cultivars. The smallest variation of this characteristic at 56 days compared with 28 DAT may have been due to the osmotic adjustment process whereby plants, under water deficit conditions, actively accumulate sugars, organic acids and ions in the cell cytosol to decrease the osmotic potential and therefore maintain the water potential and turgor of the cells near their optimum level (VERSLUES et al., 2014; LAKSMANAN; ROBINSON, 2014).

In this study, it was observed that the SPAD index was reduced in cultivars considered as susceptible to water deficit, both at 28 and 56 DAT. Several studies have reported that plants under water deficit have lower SPAD index (ZHAO et al., 2010; SILVA et al., 2011; SILVA et al. 2014a; ZHAO et al., 2013). The SPAD index is a measure that estimates chlorophyll content of leaves (MARKWELL et al., 1995; GUIMARÃES et al., 1999). The reduction of the SPAD index in plants under water deficit occurs because there is chlorophyll degradation because of water deficit, which may be the result of photodegradation (LONG et al., 1994).

Although the SPAD index is reduced in plants subjected to water deficit, Silva et al. (2011) observed that reduction is lesser in water deficit tolerant cultivars; therefore, the authors reported that the SPAD index can be a reliable physiological characteristic for classification as tolerant genotypes; the main advantage is that it is a nondestructive and easy to apply technique. Silva et al. (2014a) reported that water deficit tolerant cultivars have SPAD index above 40.0; these values were also observed in this study, where the tolerant cultivars SP81-3250 and SP83-2847, in drought situations, showed SPAD index 40.70 and 42.46 at 28 DAT and 46.53 and 47.86 at 56 DAT, respectively. Thus, water deficit susceptible genotypes do not have as much ability to synthesize chlorophyll, resulting in lower photosynthetic rates and lower stem yield (SILVA et al., 2014a).

The reduction in Fv/Fm and SPAD index in sugarcane plants under water stress may be linked to the reduction of the levels of chlorophyll $a$ of plants under water deficit (Table 4). However, for all characteristics obtained from leaf chlorophyll extraction the effect was greater of the water deficit than the cultivars. The water deficit reduced all characteristics of leaf chlorophyll at 28 and 56 DAT. While in relation to cultivars, lower values of Chl $a$ and Chl total were observed only at 28 DAT (Tables 7 and 8).

Water stress reduced RWC in all cultivars; however, there was no difference among cultivars. Sato et al. (2010) observed that water stress reduced RWC in cultivar RB867515. However, Grace et al. (2010) observed a difference in RWC for sugarcane cultivars subjected to water deficit. Silva et al. (2014a) found no correlation between RWC and yield in various sugarcane genotypes. The relative water content expresses the percentage of water present in plant tissues at the time of collection; thus, this variable can vary depending on the type of drought rate, time of drought and time of collection.

Reduction in chlorophyll content in plants under water stress has been shown by several authors. Argenta et al. (2001) observed a positive correlation between SPAD index and leaf Chl $a, b$ and Chl total. In sugarcane cultivars under water stress in the soil, there was gradual reduction in the content of chlorophyllian pigments; however, this reduction varied according to severity of stress, duration of stress and degree of tolerance and/or sensitivity of sugarcane (SILVA et al., 2011, 2014b). Carlin et al. (2012) observed that the concentration of chloroplastid pigments (Chl $a, b$ and total) decreased sharply in sugarcane plants under water deficit, and there were no changes in the chlorophyll $a / b$ ratio $(\mathrm{Chl} a / b)$. However, Silva et al. (2010) evaluated the effect of water deficit in six sugarcane genotypes but they did not find a response pattern for $\mathrm{Chl} a, b$, and $a / b$. Therefore, further research is necessary to investigate the relationship of this physiological characteristic.

\section{CONCLUSIONS}

Drought has affected the development of all cultivars and their physiological variables. 
However, larger reductions have occurred in susceptible cultivars (RB855453 and RB72454). These differences observed are in line with the classification of these cultivars as regards sensitivity to water deficit in terms of biomass production. Cultivars classified as tolerant (SP81-3250 and SP83-2847) had higher SPAD index values at 28 and $56 \mathrm{DAT}$, as well as the $\mathrm{Fv} / \mathrm{Fm}$ of the tolerant cultivars was higher at 28 DAT.

The dry matter production of tolerant cultivars had smaller decreases in leaf and stem under water deficit conditions. These physiological variables $(\mathrm{Fv} / \mathrm{Fm}$ and SPAD index $)$ are features that can assist sugarcane breeding programs in the identification and selection of water deficit tolerant cultivars, and also help the recommendation of these cultivars for harsh environments, thus minimizing the effects of drought on stem yield in the culture of sugarcane.

\section{ACKNOWLEDGMENTS}

The authors thank the São Paulo Agency for Agribusiness Technology (APTA) for allowing the use of its facilities, the São Paulo Research Foundation (FAPESP) for supporting this research (Proc. 2008/57068-8), and the National Council for Scientific and Technological Development (CNPq, Brazil) for "Productivity in Research" Fellowship (Proc. 311255/2012-4) to the first author.

RESUMO: Uma forma de minimizar os impactos causados pelo déficit hídrico (DH) na agricultura é o uso de cultivares tolerantes. A avaliação fisiológica das plantas através da eficiência quântica potencial do fotossistema II (Fv/Fm) e do índice SPAD pode se tornar uma ferramenta eficiente na seleção e recomendação de cultivares tolerantes ao déficit hídrico. Com base nesse contexto, o objetivo deste trabalho foi avaliar as respostas fisiológicas de cultivares de cana-de-açúcar classificadas como tolerantes e susceptíveis ao déficit hídrico. O experimento foi realizado na região do município de Jaú/SP/Brasil em casa de vegetação, entre os meses de julho e dezembro de 2013. O delineamento experimental foi inteiramente casualizado no esquema fatorial 4 x 2, com quatro repetições. Foram estudadas quatro cultivares de cana-de-açúcar: RB72454, RB855453 (susceptíveis ao DH), SP81-3250 e SP83-2847 (tolerantes ao DH) em dois regimes hídricos (com e sem déficit). O DH reduziu a massa seca dos colmos de todas cultivares, porém, as maiores quedas foram observadas nas cultivares susceptíveis ao DH, em que nas cultivares RB855443 e RB72454 a queda foi de 58,3 e 74,5\%, respectivamente. Já para as cultivares SP81-3250 e SP83-2847 (tolerantes), a redução foi de 44,1 e 47,7\%, respectivamente. As cultivares tolerantes ao déficit hídrico tiveram menor redução na eficiência quântica potencial do fotossistema II e no índice SPAD, demonstrando, portanto, que os parâmetros fisiológicos (Fv/Fm e índice SPAD) são características que podem auxiliar a identificação e seleção de cultivares tolerantes ao déficit hídrico, e ainda, auxiliar a recomendação dessas cultivares para ambientes desfavoráveis, minimizando os efeitos do déficit hídrico sobre o rendimento de colmos na cultura da cana-de-açúcar.

PALAVRAS-CHAVE: Saccharum spp.. Índice SPAD. Estresse hídrico. Eficiência quântica potencial do fotossistema II. Pigmentos fotossintéticos.

\section{REFERENCES}

BAKER, N. R. Light-use efficiency and photoinhibition of photosynthesis in plants under environmental stress. Smith, J. A. C. \& Griffiths, H. (Eds.). Water deficit plant responses from cell to community. Oxford: Bios Scientific Publishers, 1993. p. 221-235.

BATCHELOR, C. H.; SOOPRAMANIEN, G. C.; DAVIS, R. M. Influence of moisture stress on sugar cane leaf and stem extension. Revue Agricole et Sucrière de I'lle Maurice, v. 71, p. 312-323, 1992.

BARBOSA, A. M.; GUIDORIZI, K. A.; CATUCHI; T. A.; MARQUES, T. A.; RIBEIRO R. V.; SOUZA G. M. Biomass and bioenergy partitioning of sugarcane plants under water deficit. Acta Physiologiae Plantarum, v. 37, p. 1-8, 2015. https://link.springer.com/article/10.1007/s11738-015-1887-7 https://doi.org/10.1007/s11738-015-1887-7

BJÖRKMAN, O.; POWLES, S. B. Inhibition of photosynthetic reactions under water stress: interaction with light level. Planta, v. 161, p. 490-504, 1984. https://link.springer.com/article/10.1007\%2FBF00407081 https://doi.org/10.1007/BF00407081 
CARLIN, S. D.; RHEIN, A. F. L.; SANTOS, D. M. Efeito simultâneo da deficiência hídrica e do alumínio tóxico no solo na cultivar IAC91-5155 de cana-de-açúcar. Semina: Ciências Agrárias, v. 33, p. 553-564, 2012. http://dx.doi.org/10.5433/1679-0359.2012v33n2p553

CIGANDA, V.; GITELSON, A.; SCHEPERS, J. Vertical profile and temporal variation of chlorophyll in maize canopy: quantitative "crop vigor" indicator by means of reflectance-based techniques. Agronomy Journal, v. 100, p. 1409-1417, 2008. https://dx.doi.org/10.2134/agronj2007.0322

CONAB - Companhia Nacional de Abastecimento: Levantamento de Safra. http://www.conab.gov.br. Accessed August 31, 2016.

DANTAS NETO, J. D.; FIGUEREDO, J. L. C.; FARIAS, C. H. A.; AZEVEDO, H. M.; AZEVEDO, C. A. V. Resposta da cana-de-açúcar, primeira soca, a níveis de irrigação e adubação de cobertura. Revista Brasileira de Engenharia Agrícola e Ambiental, v. 10, p. 283-288, 2006. http://dx.doi.org/10.1590/S141543662006000200006

GAVA, G. J. C.; SILVA, M. A.; SILVA, R. C.; JERONIMO, E. M.; CRUZ, J. C. S.; KÖLLN, O. T. Produtividade de três cultivares de cana-de-açúcar sob manejos de sequeiro e irrigado por gotejamento. Revista Brasileira de Engenharia Agrícola e Ambiental, v. 15, p. 250-255, 2011. http://dx.doi.org/10.1590/S1415-43662011000300005

GRAÇA, J. P.; RODRIGUES, F. A.; FARIAS, J. R. B.; OLIVEIRA, M. C. N.; HOFFMANN-CAMPO, B. C.; ZINGARETTI, S. M. Physiological parameters in sugarcane cultivars submitted to water deficit.

Brazilian Journal of Plant Physiology, v. 22, p. 189-197, 2005. http://dx.doi.org/10.1590/S167704202010000300006

INMAN-BAMBER, N. G. Sugarcane water stress criteria for irrigation and drying off. Field Crops Research, v. 89, p. 107-122, 2004. https://doi.org/10.1016/j.fcr.2004.01.018

INMAN-BAMBER, N. G.; SMITH, D. M. Water relations in sugarcane and response to water deficits. Field Crops Research, v. 89, p. 85-202, 2005. https://doi.org/10.1016/j.fcr.2005.01.023

KRAUSE, G. H.; WEIS, E. Chlorophyll fluorescence and photosynthesis: the basics. Annual Review of Plant Physiology and Plant Molecular Biology, v. 42, p. 313-349, 1991. http://www.annualreviews.org/doi/pdf/10.1146/annurev.pp.42.060191.001525 https://doi.org/10.1146/annurev.pp.42.060191.001525

LAKSHMANAN, P.; ROBINSON, N. Stress physiology: abiotic stress. In: Moore PH, Botha FC (eds) Sugarcane: Physiology, Biochemistry e Functional Biology. Iowa: Wiley, 2014. p. 411-482.

LONG, S. P.; HUMPHRIES, S.; FALKOWSKI, P. G. Photoinhibition of photosynthesis in nature. Annual Review of Plant Biology, v. 45, p. 633-662, 1994. http://www.annualreviews.org/doi/pdf/10.1146/annurev.pp.45.060194.003221 https://doi.org/10.1146/annurev.pp.45.060194.003221

MACHADO, R. S.; RIBEIRO, R. V.; MARCHIORI, P. E. R.; MACHADO, D. F. S. P.; MACHADO, E. C.; LANDELL, M. G. A. Respostas biométricas e fisiológicas ao déficit hídrico em cana-de-açúcar em diferentes fases fenológicas. Pesquisa Agropecuária Brasileira, v. 44, p. 1575-1582, 2009. http://dx.doi.org/10.1590/S0100-204X2009001200003

MALAVOLTA, E.; VITTI, G. C.; OLIVEIRA, S. A. Avaliação do estado nutricional das plantas. 2.ed. Piracicaba: Potafos, 1997. 319p. 
MARKWELL, J.; OSTERMAN, J. C.; MITCHELL, J. L. Calibration of the Minolta SPAD-502 leaf chlorophyll meter. Photosynthesis Research, v. 46, p. 467-472, 1995.

https://link.springer.com/article/10.1007/BF00032301 https://doi.org/10.1007/BF00032301

MATIN, M.A.; BROWN, J.H.; FERGUSON, H. Leaf water potential, relative water content, and diffusive resistance as screening techniques for drought resistance in barley. Agronomy Journal, v. 81, p. 100-105, 1989. https://dx.doi.org/10.2134/agronj1989.00021962008100010018x

MAXWELL, K.; JOHNSON, G. N. Chlorophyll fluorescence - a practical guide. Journal of Experimental Botany, v. 51, p. 659-668, 2000. https://doi.org/10.1093/jexbot/51.345.659

https://doi.org/10.1093/jexbot/51.345.659 https://doi.org/10.1093/jxb/51.345.659

PIMENTEL, C. Photoinhibition in a C4 plant, Zea mays L.: a minireview. Theoretical and Experimental Plant Physiology, v. 26, p. 157-165, 2014. https://dx.doi.org/10.1007/s40626-014-0015-1

PINCELLI, R. P.; SILVA, M. A. Alterações morfológicas foliares em cultivares de cana-de-açúcar em resposta à deficiência hídrica. Bioscience Journal, v. 28, p. 546-556, 2012.

PORRA, R. J.; THOMPSON, W. A.; KRIEDEMANN, P. E. Determination of accurate extinction coefficients and simultaneous equations for assaying chlorophylls $a$ and $b$ extracted with four different solvents: verification of the concentration of chlorophyll standards by atomic absorption spectroscopy. Biochimica et Biophysica Acta, v. 975, p. 384-394, 1989. https://doi.org/10.1016/S0005-2728(89)80347-0

RIBEIRO, R.V.; MACHADO, R.S.; MACHADO, E.C.; MACHADO, D.F.S.P.; MAGALHÃES FILHO, J.R., LANDELL, M.G.A. Revealing drought-resistance and productive patterns in sugarcane genotypes by evaluating both physiological responses and stalk yield. Experimental Agriculture, v. 49, p. 212-224, 2013. https://doi.org/10.1017/S0014479712001263

SATO, A. M.; CATUCHI, T. A.; RIBEIRO, R. V.; SOUZA, G. M. The use of network analysis to uncover homeostatic responses of a water deficit-tolerant sugarcane cultivar under severe water deficit and phosphorus supply. Acta Physiologiae Plantarum, v. 32, v. 1145-1151, 2010. https://doi.org/10.1007/s11738-010-0506-x

SILVA, M. A.; SILVA, J. A. G.; ENCISO, J.; SHARMA, V.; JIFON, J. Yield components as indicators of drought tolerance of sugarcane. Scientia Agricola, v. 65, p. 620-627, 2008. http://dx.doi.org/10.1590/S010390162008000600008

SILVA, M. A.; JIFON, J. L.; SANTOS, C. M.; JADOSKI, C. J.; SILVA, J. A. Photosynthetic capacity and water use efficiency in sugarcane genotypes subject to water deficit during early growth phase. Brazilian Archives of Biology and Technology, v. 56, p. 735-748, 2013. http://dx.doi.org/10.1590/S151689132013000500004

SILVA, M. A.; JIFON, J. L.; SHARMA, V.; SILVA, J. A. G.; CAPUTO, M. M.; DAMAJ, M. B.; GUIMARÃES, E. R.; FERRO, M. I. T. Use of physiological parameters in screening water deficit tolerance in sugarcane genotypes. Sugar Tech, v. 13, v. 191-197, 2011. http://doi.org/10.1007/s12355-011-0087-z

SILVA, M. A.; JIFON, J. L.; DA SILVA, J. A. G.; DOS SANTOS, C. M.; SHARMA, V. Relationships between physiological traits and productivity of sugarcane in response to water deficit. Journal of Agricultural Science, v. 152, p. 104-118, 2014a. https://doi.org/10.1017/S0021859612000834

SILVA, M. A.; SANTOS, C. M.; VITORINO, H. S.; RHEIN, A. F. L. Pigmentos fotossintéticos e índice SPAD como descritores de intensidade do estresse por deficiência hídrica em cana-de-açúcar. Bioscience Journal, v. 30, p. 173-181, 2014b.

SMIT, M. A.; SINGELS, A. The response of sugarcane canopy development to water stress. Field Crops Research, v. 98, p. 91-97, 2006. https://doi.org/10.1016/j.fcr.2005.12.009 
TORRES NETTO, A.; CAMPOSTRINI, E.; OLIVEIRA, J. G.; SMITH, R. E. B. Photosynthetic pigments, nitrogen, chlorophyll $a$ fluorescence and SPAD-502 readings in coffee leaves. Scientia Horticulturae, v. 104, p. 199-209, 2005. https://doi.org/10.1016/j.scienta.2004.08.013

VERSLUES, P. E.; BHASKARA, G. B.; KESARI, R.; KUMAR, M. N. Drought tolerance mechanisms and their molecular basis. In: Jenks M. A.; Hasegawa P. M. (eds). Plant Abiotic Stress. Iowa: Wiley, 2014. p. 1538. https://doi.org/10.1002/9781118764374.ch2

WACLAWOVSKY, A. J.; SATO, P. M.; LEMBKE, C. G.; MOORE, P. H.; SOUZA, G. M. Sugarcane for bioenergy production: an assessment of yield and regulation of sucrose content. Plant Biotechnology Journal, v. 8, p. 1-14, 2010. https://doi.org/10.1111/j.1467-7652.2009.00491.x

ZHAO, D.; GLAZ, B.; COMSTOCK, J. C. Sugarcane leaf photosynthesis and growth characters during development of water-deficit stress. Crop Science, v. 53, p. 1066-1075, 2013.

https://doi.org/10.2135/cropsci2012.09.0554 